Ekaterina Zavidovskaia, Polina Rud

\title{
Popular Religion in Early Republican China Based on Vasilii Alekseev's Materials from to the Peter the Great Museum of Anthropology and Ethnography RAS (fund No. 2054) ${ }^{1}$
}

DOI 10.17816/wmo56798

Abstract: One of the founding fathers of Russian sinology Vasiliy Mikhailovich Alekseev (1881-1951) had acquired an impressive collection during his ethnographic expedition to the southern regions of China (May 4 - August 19, 1912), which was organized by the Russian Committee for Middle and East Asia Exploration and initiated by the Committee's head, founder academician Vasilii Vasilievich Radlov (1837-1918). Alekseev's expedition stated from Vladivostok and passed through Harbin, Shanghai, Ningbo, Putuoshan, Fuzhou, Xiamen, Shantou, Guangzhou and ended up in Hong Kong. Alekseev has collected about 1083 artifacts making up "a collection exclusively on popular Buddhist and Daoist religion, items of household usage, daily life and cult, as well as revolutionary leaflets and posters of 1912", 2 now this collection is kept at the Peter the Great Museum of Anthropology and Ethnography of the Russian Academy of Sciences (MAE, RAS) with registration No. 2054. During his earlier studies in China in 1906-1909 Alekseev acquired large collections of ethnographic materials and folk art (mainly popular woodblock prints nianhua 年畫) from the northern regions of China, which had later for the most part entered collections of the State Hermitage and the State Museum of the History of Religion (GMIR) in St. Petersburg. For his expedition of 1912 Alekseev had lined out a plan based on his observations of northern religious practices, e.g. he was particularly interested in the worship of City God chenghuang, child giving goddesses niangniang and God of Wealth caishen, but he quickly realized how different was the southern religious terrain and focused on local specifics.

(C) Ekaterina A. Zavidovskaia, PhD (Philology), assistant professor, National Tsing Hua University, Taiwan (katushaza@yahoo.com)

(C) Polina V. Rud, Research Fellow, Peter the Great Museum of Anthropology and Ethnography (Kunstkamera) of the Russian Academy of Sciences (prud@kunstkamera.ru)

${ }^{1}$ This publication was supported by the RFBR grant 19-59-52001 MHTa "Trade, Folk Be- liefs, Art and Culture on Chinese Traditional Xylographic Pictures from Scantily Studied Col-lections of Russia and Taiwan".

${ }^{2}$ AleKseev 2012: 497. 
This paper discusses a large portion of printed ritual texts used for religious purposes in Fujian and Guangdong provinces and dated by the early 20th c. Our survey of several dozens of printed materials from fund No. 2054 reveals prevalence of documents used by ritual specialists - Daoists for funerary rituals and ancestor worship, funeral various types of talismans occupy a central place. Apparently, the form and content of these texts have been preserved in the local religious practice up to present days.

Key words: Vasilii M. Alekseev (1881-1951), MAE, RAS, Daoist ritual documents, talisman, salvation ritual, image

\section{Introduction}

Parts of Alekseev's travel diary, which he carefully kept during his expedition in 1912, have been added to the new edition of Alekseev's travelogue $V$ Starom Kitae (In Old China, 2012, first edition 1958) by the volume's editor Boris L. Riftin. ${ }^{3}$ T. Vinogradova's research on Alekseev's diaries catalogued in his "sinological file cabinet" revealed that there were diaries from Ningbo and Canton (Guangzhou), which whereabouts are not known for certain. One of the suggestions is that they may have been handed over to the St. Petersburg Branch of the Archives of the Russian Academy of Sciences by Alekseev's family members. ${ }^{4}$ Hand notes made by the future academician during his visit to the island of Putuoshan 普陀山 (June 6-22, 1912) are kept at the State Museum of the History of Religion (GMIR). Upon his return back to Russia in 1912 Vasilii Alekseev delivered a report to the Russian Committee for Middle and East Asia Exploration about his mission. An typewritten archival inventory enumerates all acquired artifacts and becomes a very helpful source for the attribution of the ethnographic objects and various printed materials from this fund. ${ }^{5}$ Yet, some terms used in the inventory for describing

\footnotetext{
${ }^{3}$ Alekseev 2012: 444-501.

${ }^{4}$ VinOGRADOVA 2017: 240.

${ }^{5}$ This inventory allowed to track some objects which have been borrowed from MAE, RAS to be exhibited at the Antireligious exhibitions in 1930 and 1932 in Leningrad and later remained at the State Museum of the History of Religion, including a miniature statue of the child-giving goddess Jinhua niangniang 金花娘娘 (No. Л-4621/1-3-VII ГМИР-КП-20961/ 1-3) and ancestor name tablet (Б-1839-VII ГМИР-КП-19226). From personal communication with the research fellow of the GMIR Maria Kormanovskaia (April, 2020). The State Hermitage Museum on-line catalogue of woodblock prints contains around ten pieces collected by Alekseev in southern China, among them sheets No. ЛТ-6283, ЛТ-6289, ЛТ-6290 have detailed pencil notes of the collector, which are not intelligible from the screen, being
} 
various documents appear lacking accuracy, one of the goals of this study has been to clarify of these terms and purpose of the documents. In early 2020, technical staff of MAE, RAS has completed photographing and scanning of the large scope of the No. 2054 fund's objects, some of the artifacts previously unseen by anyone from outside of the Museum are analyzed in this paper, which continues the authors previous research on the Alekseev's fund No. 2054 from MAE, RAS. ${ }^{6}$

Part of Alekseev's travel diary published in 2012 mentions that acquired objects allowed "studying religion in its intimacy, instead of randomly relying on book translations or some extracts", ${ }^{7}$ which was seen by the collector as one of the most positive results of the expedition. Total amount of the objects of religious nature reached 686 pieces out of 1083. In his report Alekseev expressed intention to write a paper on "spells from Fuzhou", but did not realize his plan. Alekseev's travel notes at our disposal barely mention when and how he purchased various kinds of ritual objects. This our knowledge of their place of origin, purpose and context may only derive from consulting similar well-studied ritual documents produced in abundance by the southern popular Daoism. Written texts played important part in the liturgy of the Zhengyi 正一 Taoist school prevailing in the southeastern China. Detailed and reliable study of the sequence and meaning of Taoist ritual practice is possible if ritual manuals keyiben 科儀本 kept by the masters and field observations are both available. In our case we only have "disposable materials" like empty forms which were probably sold at temple shops and purchased by customers before the ritual. Below we take closer look at a series of textual memorials and talismans.

\section{No. 2054-191/1, 2 (PI. 1)}

Museum attributes this piece as "envelope with a prayer for happiness", envelope has rectangular piece of red paper with words "Memorial brining good fortune" zhifu shuwen 植福疏文 (No. 2054-191/2) glued on top, inside

"official documents" issued to expel evil spirit which has brought fire and other misfortunes upon a house, sheets No. ЛТ-6284, ЛТ-6288 from Guangdong prefecture are addresses to local child-giving deity Flower King huawang 花王 with images and text, these prints can be viewed by inputting object number (e.g. JT-6289) into a search window in http://collections. hermitage.ru/.

${ }^{6}$ ZAVIDOVSKAIA \& RUD 2020.

${ }^{7}$ AleKseev 2012: 497. 
6
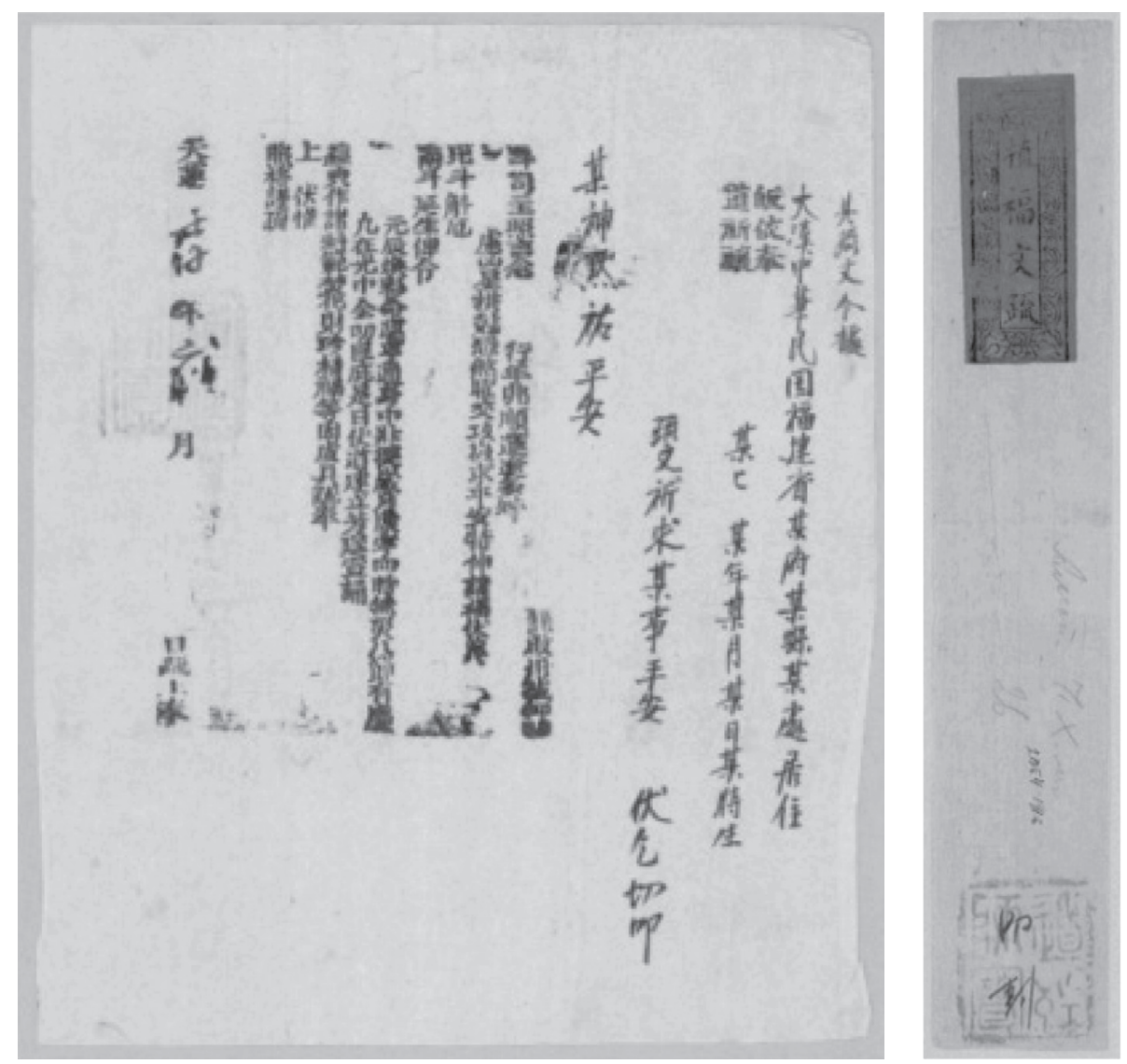

pl. 1

is a standard prayer text requiring filling in personal data. Information about location is the following: "Great Han Republic of China, Fujian province..." 大漢中華民國福建省 (there is word “Amoy” Xiamen 廈門 written in Russian with pencil on the envelope ${ }^{8}$ ), administrative units prefecture $f u$ 府, county xian 縣, address, particular date, are to be written in. To the very left there is a date: 6th of year renzi 王子 (1912). Document says: "memorial shuwen to pray for peace/luck concerning a certain matter (to be written in), pray to some deity to protect peace and make a bow". Right part of the document is hand

\footnotetext{
${ }^{8}$ In his diary Alekseev mentions that during his visit to Amoy on July 4th he was impressed by a temple festival of the City God chenghuang and was very sorry to leave Amoy so quickly (Alekseev 2012: 484).
} 
written, while memorial is printed with use of a woodblock, where we see a prayer to the Host of the Dipper department dousizhu 斗司主 to minimize influences of malicious stars, addresses to North Dipper beidou 北斗 relieving from misfortune and South Dipper nandou 南斗 prolonging lifespan. Further text mentions star influences upon human fate. We suggest that this document might have been recited in the temple upon believer's request in the beginning of a new year in order to minimize misfortunes caused by stars, since each person's birth date and hour determined different star influences he/she experienced each year, after the ceremony the memorial would be burnt with paper money.

\section{No. 2054-202/1-9 (PI. 2)}

This set of printed documents including nine sheets is termed in the $\mathrm{Mu}-$ seum inventory as "talismans for the netherworld". All sheets have similar textual part and nine different talismanic characters in the central part, talisman was seen to be the most potent part the document. All these talismans are issued by the Bureau of Great Methods of the Numinous Treasure Lingbao dafasi 靈寶大法司, related to the "Great Law of the Great Clarity Numinous Treasure” Shangqing lingbao dafa 上清靈寶大法, juan 10 by Wang Qizhen 王契真 of Northern Song. ${ }^{9}$ The ritual is performed by Heavenly master Zhang 張天師 whose full title is written to the very left of the document - Zushi santian fujiao fuyuan tianfa tianshi zhenjun 祖師三天扶 教輔元大法天師真君, ritual is conducted on behalf of the chief mourner zhaizhu 齋主, who hires ritual specialists to arrange passage chaodu 超度 of the deceased from the trials of the underworld to the paradise in the West. As mentioned in this memorial, the soul of the deceased is to be bathed, afterwards each of talisman is probably placed in one of the nine directions (south, north, west, east, center, south-east, south-west, north-west, north-east). Each direction has a Host of hell diyuzhu 地獄主, believed to be a demon-king overthrown to hell by the Bodhisattva Manjushri. Susan Huang mentioned that figure "nine" in salvation ritual is related to the ninefold darkness jiuyoujiao 九幽醮 associated with the Yellow Register fast. Taoist salvation rituals,

\footnotetext{
${ }^{9}$ In his study of Taoist rituals observed in southern Taiwan John Lagerwey mentions that Taoist Master Ch'en followed the Great Method of the Numinous Treasure founded by Ning Ch'üan-chen 寧全真 (1101-1181), whose alias was Real Man Who Saves from Distress (LAGERWEY 1987: 193), therefore ritual practice seen in Taiwan and earlier documents in this study may be considered as produced by the same school.
} 


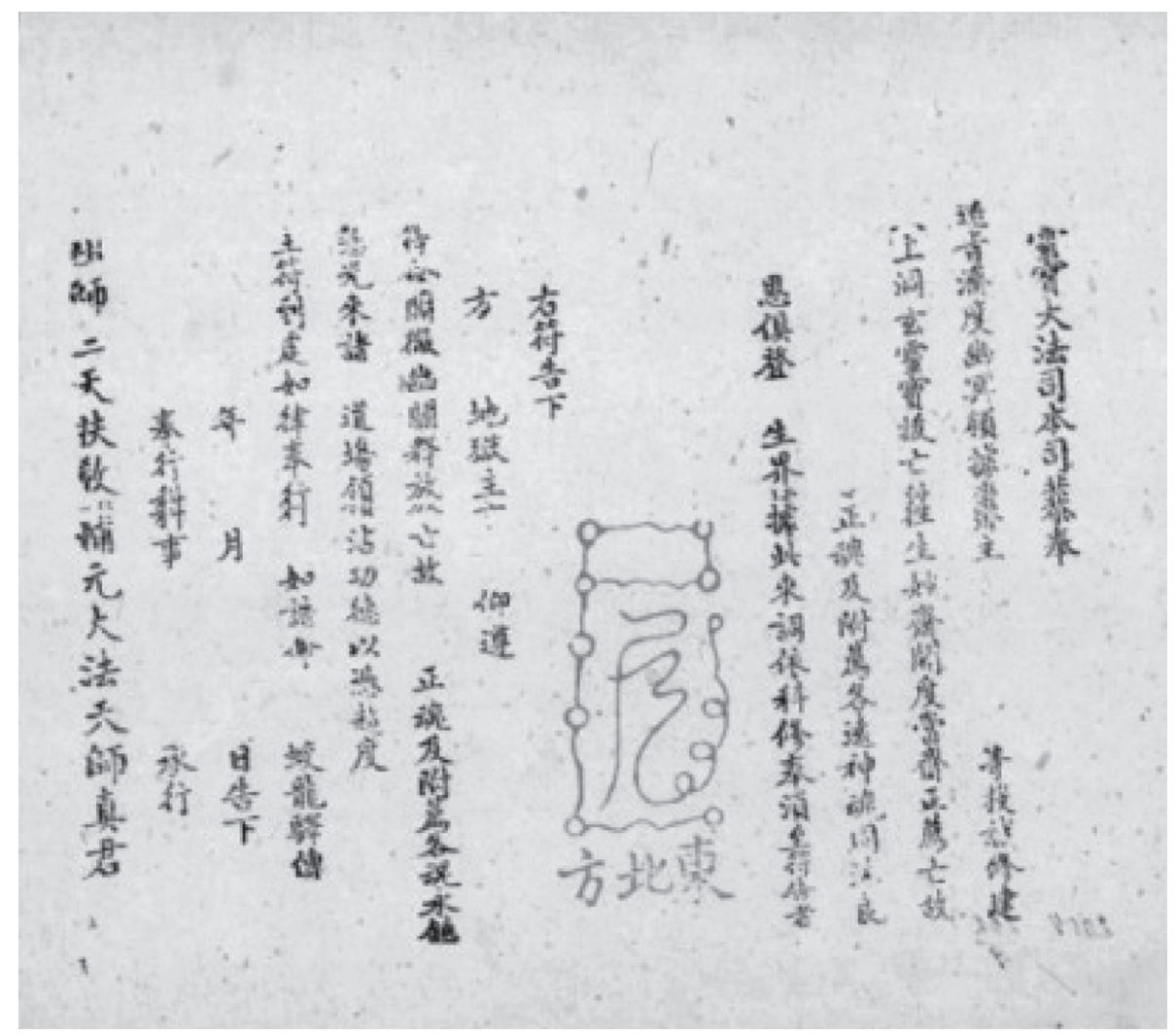

pl. 2

which grew largely after Song, had a special ritual space reserved for the souls and consisted of earth mounds marked by lamps and banners to symbolize the multichambered prisons in which the suffering souls were trapped, in the cause of the ritual the ritual master gradually moved toward main altar while leading the summoned souls onto the path of purity and salvation. ${ }^{10}$ In our case nine talismans could be placed in different directions for the souls to be saved.

In Taoist ritual, "bathing" is the name of one of the rites performed as a part of the Yellow Register fast huanglu zhai 黃筡齋 and the ritual of merit gongde 功德 for the salvation of the deceased, during which the spirit of the deceased is summoned and bathed during the ceremony of purification. After

${ }^{10}$ Huang 2015: 974. 
it has been released from the underworld, he is bathed, purified and given a change of clothes. ${ }^{11}$ Ritual of soul bathing muyu 沐浴 is mentioned as a part of initial summoning of the souls of the deceased ancestors zhaohun 招魂 on the first day of the mourning ceremony. ${ }^{12}$ It was performed to for soul saved out of netherworld during an "incense and flower" Buddhist funeral service of Guangdong province. ${ }^{13}$

Another set of printed documents discussed below seems to be a set of talismans and memorials used for the salvation ritual as well.

\section{No. 2054-217/1-9}

A series of nine sheets printed with red ink and termed as "talismans for the relief from sufferings in the upcoming life" in the inventory were probably sold as one set for the funeral service performed by Taoists. Based on the information from sheet nine (2054-217/9) we learn that this set of documents was produced in Guangdong 廣東 province. ${ }^{14}$ In his travel diary describing visit to Canton Alekseev mentioned purchasing a lot of printed materials on three cults, ${ }^{15}$ but we don't find any details on talismans related to mortuary rituals.

Sheet 2054-217/1 is covered by columns of accurately printed mystic Taoist characters representing talismans.

Sheet 2054-217/2 has vertical inscription "Genuine Talisman Saving from Distress of Yellow Register Addressing Gods" huanglu baijian jiuku zhenfu 黃錄白簡救苦真符, to the left is the talisman per se, the text to its left starts with mentioning Yuanshi fuming 元始符命 talisman, ${ }^{16}$ together with above mentioned Yellow Register talisman it is summoning one hundred and twen-

${ }^{11}$ Haruj 2013: 156.

12 JONES 2016: 76.

${ }^{13}$ TАM 2012: 48.

${ }^{14}$ Some Guangdong talismans to drive away thieves (№ 2054-187/3-1) and secure happy marriage (№ 2054-187/4-3) acquired by Alekseev in 1912 have been introduced in (ZAVIDOvsKAIA 2019: 102).

${ }^{15}$ Alekseev 2012: 489.

${ }^{16}$ In his description of a three-day ritual observed in rural Fujian K. Dean mentions this talisman in the context of the consecration kaiguang 開光 ritual, when the priest burns Yuanshi fuming talisman asking Great God of the Five Roads to open the way for the scattered hun 魂 and po 魄 souls of the deceased (DEAN 1988: 50). This talisman is originating from "Great Law of the Great Clarity Numinous Treasure” Shangqing lingbao dafa 上清靈寶大法, juan 46. 
ty soldiers, five emperors, official investigators and mighty evil spirit warriors lishi 力士 from Ten directions, Three Palaces and Nine prefectures and Nine hells for deities to make fines, for Departments of Soldiers bingsi 兵司, Official's salary lusi 祿司, Fate mingsi 命司 and Merits gongsi 功司, demon Cow head, Soldiers of hell and Six demons of three directions to save the soul (a blank for the name of the deceased) from hell and for it to turn into an ancestor and see the light, to be cleaned of sins, take up Nine prohibitions jiuzhen miaojie 九真妙戒 and be reborn in paradise.

Sheet $2054-217 / 3$ is a ritual text signed by The Supreme One, the Heavenly Venerable who Saves from Distress taiyi jiuku tianzun 太乙救苦天尊, "the principle deity to whom funeral services are directed". ${ }^{17}$ The title of the memorial called "Heavenly Treasure Register of Passing Life of the Supreme Lord” taishang baodusheng tianbaolu 太上寶度生天寶籙 is borrowed from "Great Law of the Great Clarity Luminous Treasure" Shangqing lingbao dafa 上清靈寶大法, juan 44 by Wang Qizhen, where its original title sounds like "Heavenly Luminous Register of Supreme Mysterious and Primordial Lord ordering pardoning to the living" yuanshang xuanyuan taishang chi shesheng tianbao lu 元上玄元太上敕赦生天寶籙. This whole juan of Wang Qizhen's writing is consisted of memorials and official forms relevant to the ritual of saving hungry ghosts from underworld.

The original text from "Great Law of the Great Clarity Luminous Treasure" is represented below, on the sheet No. 2054-217/3 it has been printed with slight discrepancies, representing a list of entities (prefectures, seas, peaks, passes) and deities in charge of the underworld prisons summoned for the ritual:

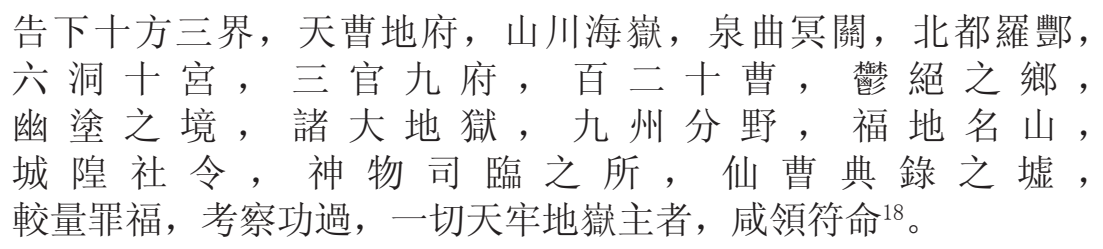

The next passage from the original memorial is omitted and continued with the passage below depicting the process of transformation into Daoist saints xian 仙, divinities and overcoming the sufferings in underworld prisons:

\footnotetext{
17 DeAn 1988: 56.

${ }^{18}$ From: https://ctext.org/wiki.pl?if=gb\&chapter=298610 (access date: May 14, 2020).
} 


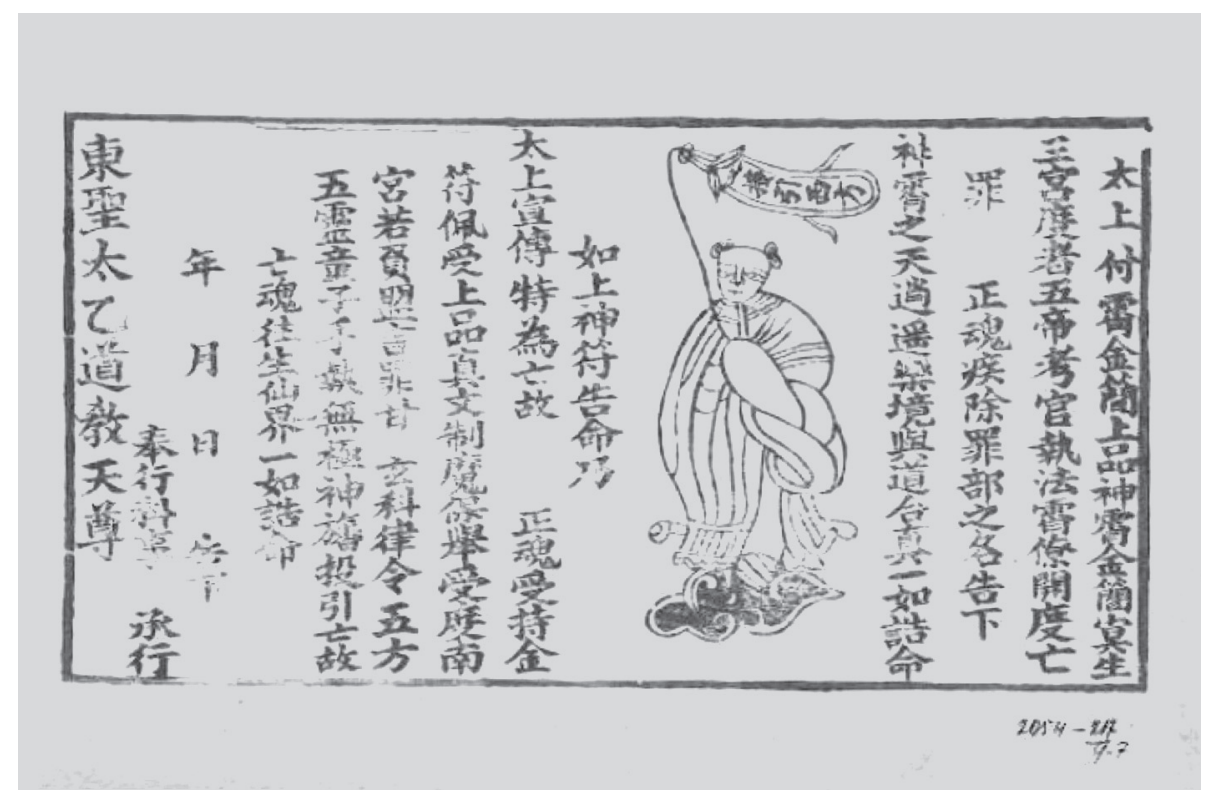

pl. 3

承此太上慈恩, 並與疾除罪簿, 落滅惡根, 不得拘留。徑出地獄, 永離幽陰, 皆證妙果。如擔砂負石、漣汲溟波之眾, 驅雷役電、 掃山穿地、貫天引水之徒, 並與斷地逮役, 永使逍遙。即令上件亡 魂, 七忢成真，六儀運虛，五靈續絕，二曜扶衰，旋綱躡空，飛步 雲宮, 胚胎有始, 塵劫元終, 金城孕質, 玉洞凝神, 真昰內養, 以 成真人。上入太虛, 下洞幽泉, 雲官寶閭, 中有真魂, 出入福鄉, 周旋生門, 咀嚼靈芝, 灌漱金泉, 甘露川流, 懸澎丹田, 紫霞朝 映, 三䲷凝煙, 瓊室化仙, 安座金蓮, 真儀掩日, 塵劫為年, 一 如告命。

The talisman is activated by the Supreme One, the Heavenly Venerable who Saves from Distress whose name is printed to the left on our document.

Sheet four (2054-217/4) contains both talisman and textual part, probably its purpose is to address the abode of the immortals xianjie 仙界 so that the host's body (the body of the deceased) is to go through the salvation and rebirth together with his soul.

Sheet five (2054-217/5) represents an order on behalf of the Three Pure Ones sanqing 三清 to transform the soul of the deceased into a "correct soul" 
zhenghun 正魂, or an ancestor, the order is supported by a circular seal Precious circle baohuan 寶環, there are blank spaces for date and a name two masters witnessing this process.

Sheet six (2054-217/6) contains a talisman and textual part which mentions "The Most Excellent and Scripture of Limitless Salvation" yuanshi duren shangpin jing 元始度人上品經 ${ }^{19}$ used to annihilate three evils, after that the saved soul to the Heavenly gate tianmen 天門 and sublimated on the Cinnabar hill zhuling 朱陵. ${ }^{20}$

Sheet seven (2054-217/7, Pl. 3) contains the image of the soul-catcher called the Lad of Five Directions and Five Souls wufang wuling tongzi 五方五靈童子, who wears boys hairstyle, carrying a soul-banner lingfan 靈 幡 with words “bring [soul] to the West" yinjie xifang 接引西方 on it, the text to the right mentions Passer from Three palaces sangong duzhe 三宮度 者, Five emperors interrogation officials wudi kaoguan 五帝考官 who can exclude the soul's sin record. The text to the right pleads the Lad to lead the soul with the banner.

Sheet nine (2054-217/9) representing a notice bang 榜 is most likely the first one used in the sequence of the salvation ritual, its purpose is to announce start of the salvation ritual and summon gods and demons to descend to the altar.

As was shown above, the sheet enumeration made by the Museum does not reflect the sequence of their use in the cause of the Taoist soul salvation ritual, which bears many features similar to the liturgy of modern Fujian and Taiwan.

\section{No. 2054-218/1-35}

This series of thirty five yellow sheets are termed as "posthumous talismans" in the inventory. Indeed, they were supposed to be used in the cause of

${ }^{19}$ This scripture from the original fifth century Lingbao corpus is related to the idea of saving those suffering in the world or in hells, depicts the salvation of the Most High Lord to ensure salvation of the ancestors (PREGADIO 2013: 150).

${ }^{20}$ Three-day funeral rite in modern Fujian also has the Calling of the Soul, the incense is offered to the Three Pure Ones and all the gods, then the chief priest recalls the great vow of the One who Saves All from Distress to save all souls, then the chief reads the Memorial and waves the soul banner. The souls are led from the underworld to the altar and on to salvation (DeAn 1988: 50). In south Taiwan the soul-banner has narrow strips with the names of the seven terrestrial souls po 魄, the wide strip is the real soul-banner; its inscription calls on the Savior from Distress to save the "correct soul(s)" cheng-hun 正魂 of the deceased from hell and ensure its passage to the paradise in the West (LAGERWEY 1987: 176). 


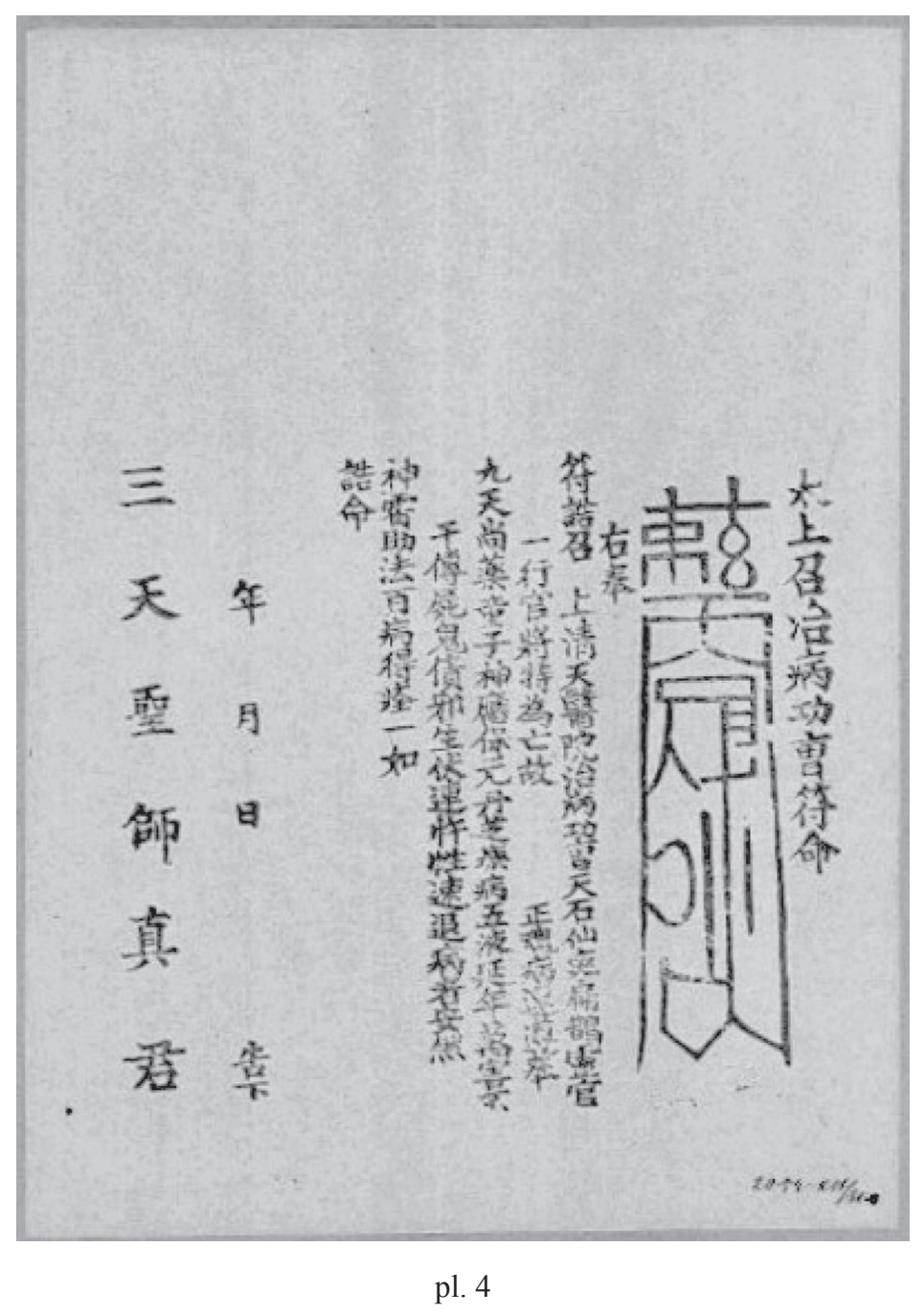

salvation ritual and present a valuable source of information, since each talisman has incantation formula explaining its meaning. The style of characters allows suggesting that this set was produced by the same shop in Guangdong along with set No. 2054-217. These talismans were used by a Taoist priest to activate such ritual acts as pardoning all the misdeeds and sins of the deceased, healing all his previous wounds and illnesses (No. 2054-218/10, Pl. 4), bathing and cleansing the body, preparing new clothes to enter the abode of the 
immortals, passing through the Gates of different death causes, summoning gods and spirits. Some of these talismans were borrowed from juan 5 of "The Jasper Mirror of the Luminous Treasure" lingbao yujian 靈寶玉鑑 ${ }^{21}$ written by unknown author of Song dynasty, which has a section "Genuine Talismans of Opening Eight Gates for Salvation" kaidu bamen zhenfu 開度八門真符, some talisman titles originate from "Great Law of the Great Clarity Numinous Treasure” Shangqing lingbao dafa 上清靈寶大法, juan 46.

\section{No. 2054-263/2 (Pl. 5)}

A printed document with text and image of the Supreme One, the Heavenly Venerable who Saves from Distress taiyi jiuku tianzun 太乙救苦天尊 inside a frame composed of auspicious objects. The inventory attributes it as "talisman", but what we see here is a "permit" for the soul of the deceased to be out from the netherworld mingtu luyin 冥途路引. Lagerway calls it “ "dark path road-puller', that is, a device like a flag for pulling the soul along the road that leads out of the underworld. It is issued in the name of the Heavenly Master of the Great Method of the Three Heavens, Chang (Tao-ling), and is addressed to the Savior from Distress, whose image appears between the end of the text and title of the Heavenly Master". ${ }^{22}$ It is important to note that, the design of the document observed in southern Taiwan in 1980s basically matches the one from Alekseev's collection, which was produced in Guangdong province. When discussing funerary practices of Guangdong Li Zhitian mentions that mingtu luyin 冥途路引, or “road passport” lupiao 路票, is issued to the souls of the deceased by Taoist be means of burning this passport, which says that the Supreme One, the Heavenly Venerable who Saves from Distress offers the passport to the soul so that no obstacles are created on its way by various hell departments and checkpoints, in other words, such passport guarantees smooth traveling of the soul out of the underworld. ${ }^{23}$

A document identical to No. 2054-263/2 is kept in the collection of GMIR (No. Д-3272-VII), Alekseev probably sold it to the Museum in 1938 together with around one thousand other pictures and objects. In our previous paper we have discussed "license for the soul of the deceased" shenhun zhizhao

\footnotetext{
${ }^{21}$ https://ctext.org/wiki.pl?if=gb\&chapter=453122 (access date: June 8, 2020).

22 LAGERWEY 1987: 199.

${ }^{23}$ Li 2007: 213.
} 


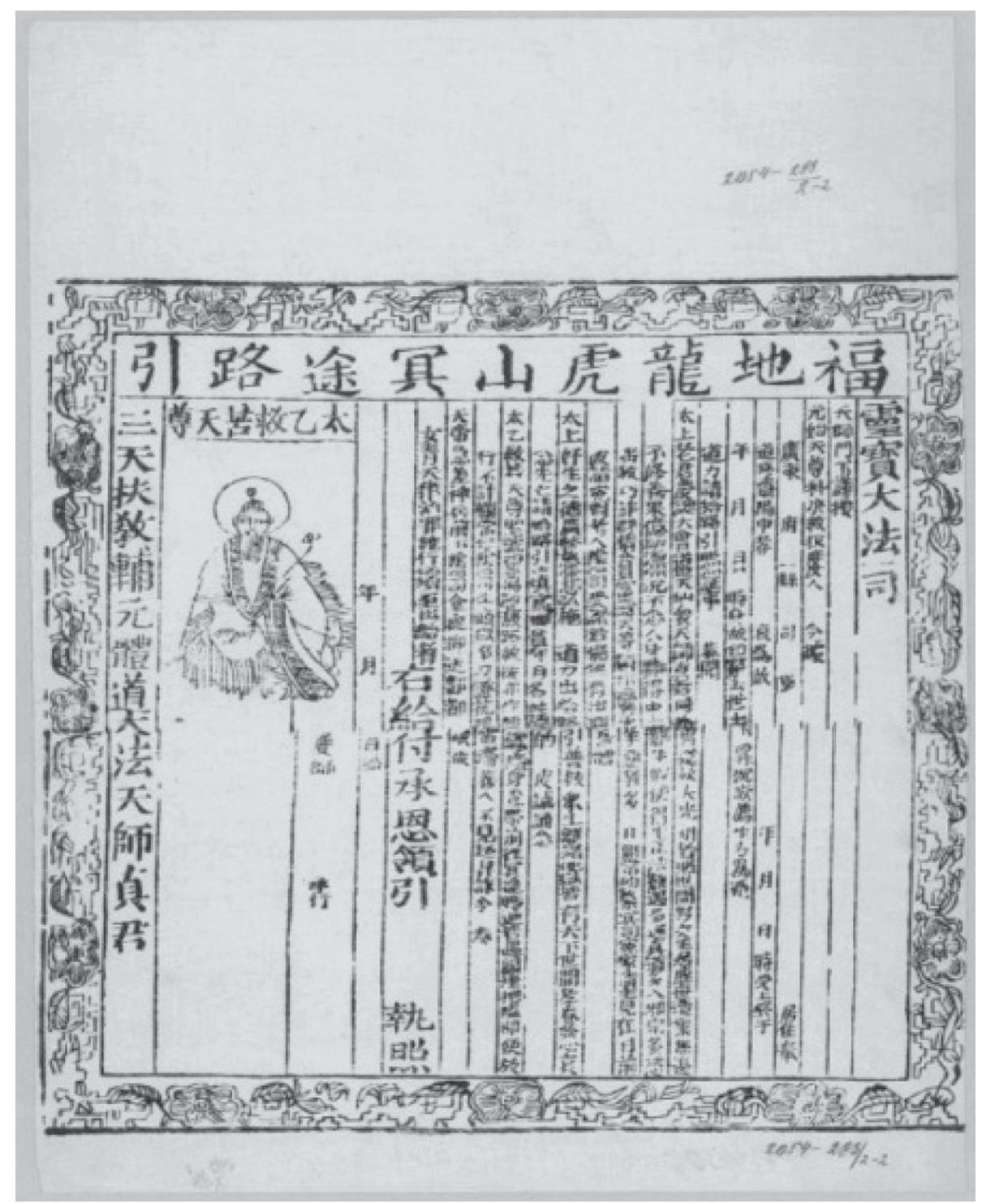

pl. 5 
神魂執照, ${ }^{24}$ which "the soul of the deceased receives after bathing and putting on clean clothes, and it is transmitted to it by the 'servant' of the Three Pure Ones, that is, the priest, whose ordination has made him an 'immortal official'. In this ritual the priest is making the soul of the deceased a Taoist initiate, an initiation that is at once comparable to and dependent upon his own ordination". ${ }^{25}$ Therefore two documents, "dark road-puller" and "soul passport", were used during the stages of the salvation ritual.

\section{No. 2054-232/1-12}

In the inventory a series of twelve talismans and characters printed on orange paper with black ink are termed as "incantation formulas", but this term does not seem to be accurate. They are: tianyi 天乙, $k u n$ 坤, $l i$ 離, $d u i$ 兌, zhen 震, kan 坎, dingfu 定福, guiren 貴人,jinma 金馬, yutang 玉堂, tongchun 同 春, liuhe 六合. Among them kun 坤, $l i$ 離, dui 兌, zhen 震, kan 坎 represent

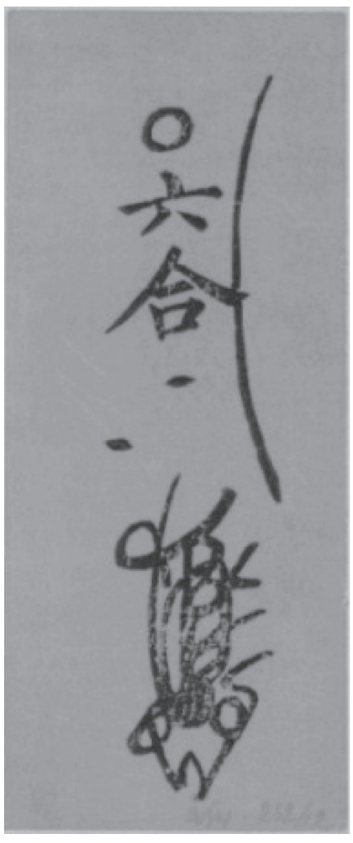

pl. 6 four out of eight hexagrams, therefore this set of prints was probably used for divination purposes, supposedly, to determine person`s luck. Tianyi 天 乙 is one of the four basic astral forces that may bring luck and misfortune upon a person, guiren 貴 人 is a term describing some helping person or an auspicious deity (in this case they are stars), who could positively affect one's fortune. Divination methods based on "eight birth characters" aim to determine a guiren star of a particular parson. Notions jinma 金馬 (“golden horse") and yutang 玉堂 ("jade hall") are probably metaphors for respectful address an to academician of Hanlin academy, in divination practice they may be used to determine person`s chances during exams; tongchun 同春 as a part of the wish for longevity guihe tongchun 龜鶴 同春, could be used to determine person`s life span, liuhe 六合 “six cardinal points" (No. 2054-232/12, P1. 6) was widely used by diviners to check whether a man and a woman are suitable for marriage.

${ }^{24}$ ZAVIDOVSKAIA \& Rud 2020: 271-272.

${ }^{25}$ Lagerwey 1987: 184. 


\section{No. 2054-197/1-5}

A series of five sheets of different color with the same talisman, text and image printed with black ink, the talisman contains an image of a boy (probably deity Mangshen 芒神) holding a banner with words "Clay ox gives peace and protects" tuniu anzhen 土牛安鎮 with a "clay ox"26 depicted next to a boy. The inventory marked this series as "farmers" talismans". The printing board and writing on it are rather coarse, which is a characteristic of the cheapest products consumed by common folks (No. 2054-197/1, pl. 7). The phrase on top "Talisman of the Highest for pacifying earth” taishang antu fuming 太上安土符命 points at the widely spread practice of using talismans to pacify earth spirits of five directions, who could be disturbed by people digging the ground, for instance, in the result of digging a grave. We also have five talismans matching five directions, therefore they are probably a set. Juan 30 of the collection of Daoist religious texts "The Reprieved Pearls from the Sea of Methods" fahai yizhu 法海 遺珠 by unknown author of late Yuan early Ming period contains "Earth pacifying talismans of five directions" wufang antu fu 五方 安土符, whose purpose is to address Dragon Kings of Five Directions protecting a lodging wufang zhenzhai longwang 五方鎮宅龍王. ${ }^{27}$ Our talisman is signed by Heavenly Worthies Five Saints Dragon Kings bringing peace taisheng wulong anzhen tianzun 太聖五龍 安鎮天尊. In this case talisman concerns probably Yin lodging yinzhai 陰宅, a term for a grave.

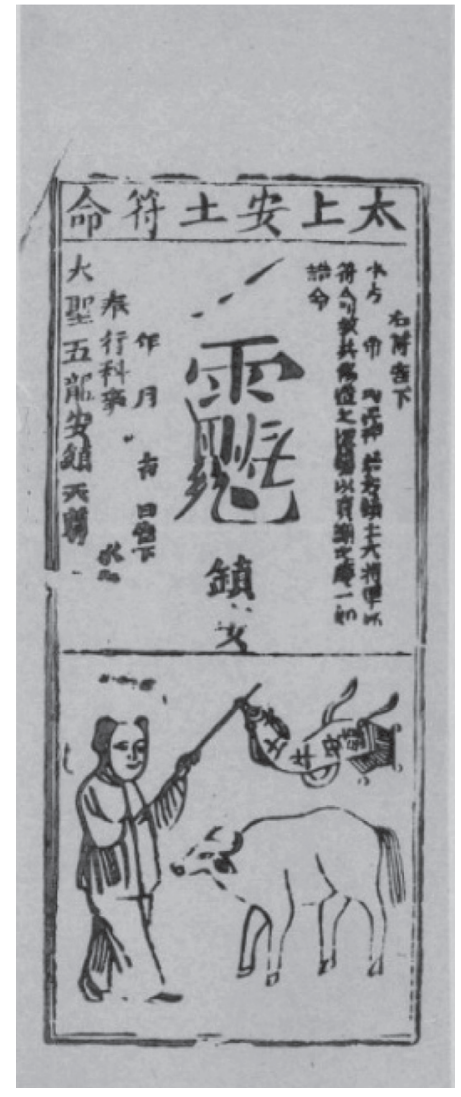

pl. 7

${ }^{26}$ Earth, or clay, ox tuniu 土牛 is normally associated with the ritual of beating an ox figure made of clay and welcoming spring rather than funerary practice.

${ }^{27}$ Five Dragon Kings are mentioned as protectors of the grave in various Daoist documents. 


\section{No. 2054-372/1-19}

We may be certain that this set of paper icons zhima 紙馬 was produced in Foshan 佛山, the largest centre of woodblock prints production in southeastern China. Inventory terms them as "popular prints, images of Liuhai 劉 海 and Hehe 和合”. Alekseev could have purchased them either in Guangzhou or in Shantou, where Foshan printing shops had multiple branches. One of the features of Foshan paper icons was to use colored paper with one color imprint made with black ink, gold color was probably added in some parts by hand. Our icons have similar composition: on top tier is an image of two figures -

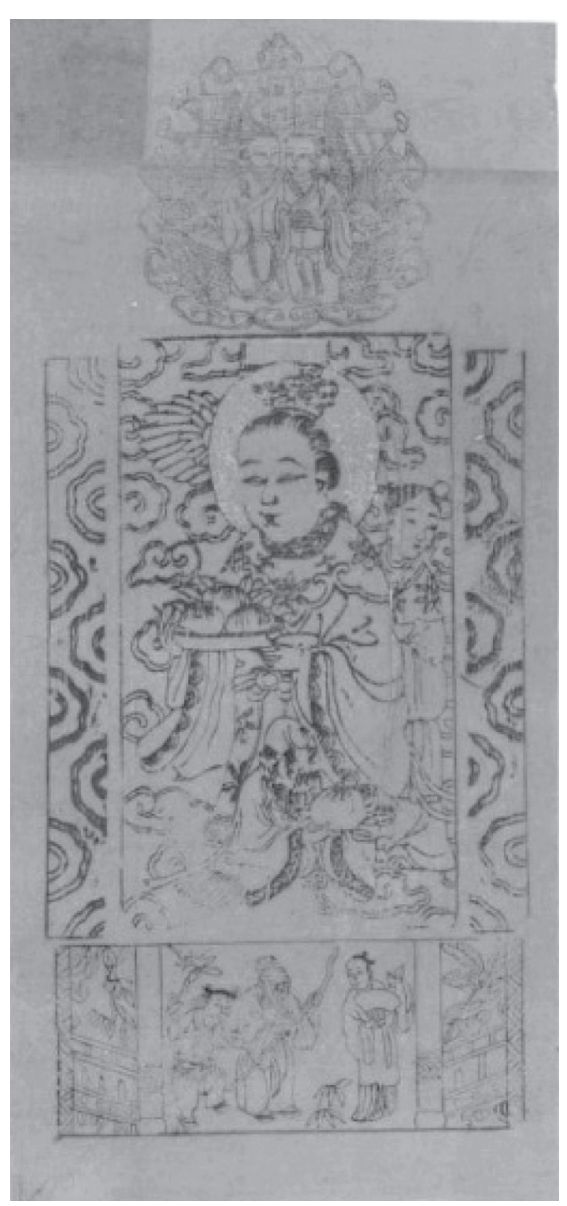
probably gods of harmony Hehe 和合, on the bottom level there are compositions with human figures, but who are the deities in the centre? On the sheet No. 2054-372/17 (pl. 8) we probably see Nezha 哪咤 wearing a princely crown holding longevity peaches on a tray, below him stands Longevity god Shouxing 壽星 with a peach. On the sheet No. 2054-372/16 a female figure in the centre is most likely the Queen of the West Xiwangmu 西王 母 also holding a tray with peaches and Shouxing flying a crane below her. Such icons could be used for the 60th birthday celebration or for some ritual of praying for longevity of an elder family member.

pl. 8 


\section{Conclusion:}

\section{Regional Variations in Talisman Usage}

One of the objectives of this study has been to reveal and summarize regional specifics of early Republican popular religion based on the printed objects brought by Vasilii M. Alekseev from South China. Apparently, Alekseev purchased printed Taoist ritual documents texts \& drawings without being able to look through them in detail and observe the process of their application in the ritual practice. Yet he was rather familiar with Chinese talismans per se, since he had acquired several dozens of them during his studies in China in 1906-1909, now most of them are stored at the GMIR. ${ }^{28}$

What makes northern talismans different from southern ones is that majority of them are painted with a brush with Zhang Daoling's 張道陵 magic stamp on top and serve concrete purposes such as driving away evil spirits (No. Д-2848-VII, pl. 9), "five poisonous creatures", curing illnesses etc. Due to his interest for "demon conqueror" Zhong Kui, Alekseev purchased large amount of talismans and pictures related to Duanwu 端午 festival (No. Д-2828-VII, pl. 9), which make up a large part of his collection of northern talismans. Notably, northern talismans do not bear obvious signs of being a part of a larger ritual, neither do specimens collected by Alekseev relate to salvation ritual, which appears to be central for the southern tradition judging from randomly selected prints from fund No. 2054 in MAE RAS. Northern talismans seem to have been bought straight by their end users, rural and urban believers, from producers, who could be either "roaming Daoists" or some shops associated with them. Afterwards people just glued talismans on the wall or burned them with paper money after chanting an incantation (this part could be performed by a professional for a pay). ${ }^{29}$ Shape and content of northern talismans reflects the status and role of Daoists in the northern regions of China, where monastic tradition of Quanzhen 全鎮 Daoism prevailed. As for the southern specimens discussed in this paper, they represent

$28 \mathrm{http} / / /$ alekseev-collection.gmir.ru/en/catalog-eng/category/fu-talismans (Access date: June 19, 2020). Among them longevity talisman № Д-3303-VII has Alekseev’s stamp, also produced in southern China in 1912.

29 James Hayes characterizes charm producers in late imperial China in the following way: "The provision of charms was an important service for communities as well as for individuals. Specialist practitioners were often called upon by communities when they were thought to be imperiled by evil forces that made themselves felt through sickness and death of animals and humans. The ritual and charm specialists could be found in most subdisctricts and even in many of the larger villages" (HAYES 1985: 97). 

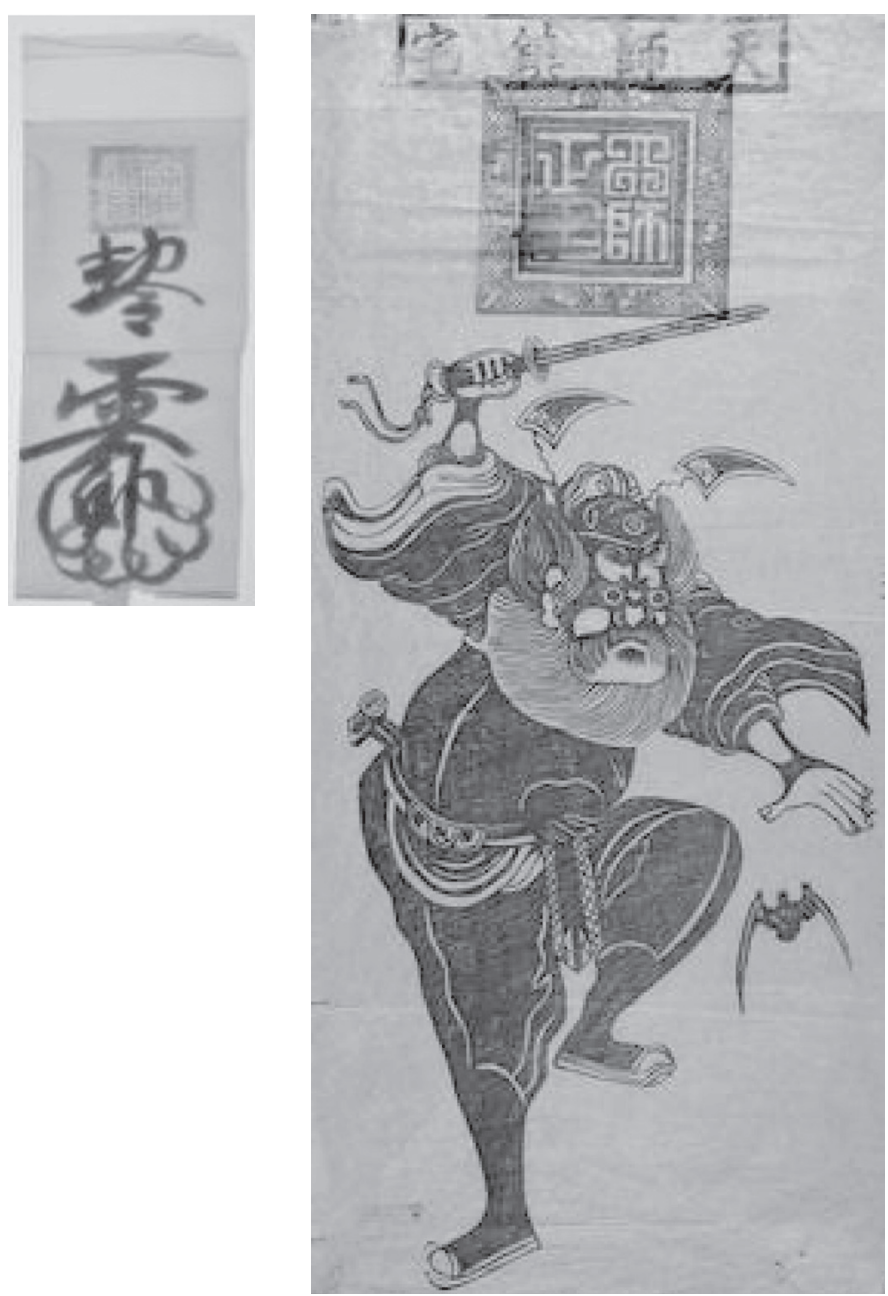

pl. 9

just one aspect of the funerary ritual practice, which was carried on by priests with use of special liturgical books keyiben 科儀本, accompanied by music, chanting and ritual actions, and these aspects are not reproducible based just on the documents we have. Yet it would be legible to claim that tradition of "Great Law of the Great Clarity Numinous Treasure" seems to have been prevailing in the area of Fujian and Guangdong provinces. Nevertheless, a larger portion of documents collected by Alekseev needs to be thoroughly studied in order to make final conclusions about regional specifics. 


\section{References}

Alekseev, Vasilii 2012: V starom Kitae [In Old China]. Ed by Boris L. Riftin. Moscow: Vostochnaia Literatura.

HARUII, Asano 2013: Bathing: ablutions. The encyclopedia of Taoism. Ed. by F. Pregadio. London; New York: Routledge, 156.

HAYEs, James 1985: Written materials in the village world. Popular Culture in Late Imperial China. Ed. by Johnson D. \& Nathan A.J. \& Rawski E.S. Berkeley: University of California Press.

Huang, Susan Shin-shan 2015: Taoist Visual Culture. Modern Chinese religion I: Song-LiaoJin-Yuan (962-1368 A.D.). Ed. by J. Lagerwey, P. Marsone. Leiden-Boston: Brill: 9291050.

JoNES, Stephen 2016: In Search of the Folk Daoists of North China. London-New York: Routledge.

Lagerwey, John 1987: Taoist Ritual in Chinese Society and History. New York-London: Macmillan.

LI, Zhitian 黎志添 2007: Guangdong defang daojiao yanjiu: daoguan, daoshi ji keyizhe 廣東地 方道教研究：道觀、道士及科儀著 [Study of local Guangdong Daoism: Daoist temples, Daoists and ritual performers]. Hong Kong: Zhongwen daxue chubanzhe.

Pregadio, Fabrizio ed. 2013: The Encyclopedia of Taoism. London-New York: Routledge.

TAM, Yik Fai 2012: Xianghua foshi (incense and flower Buddhist rites): a local Buddhist funeral ritual tradition in southeastern China. Buddhist Funeral Cultures of Southeast Asia and China. Ed. by Paul Williams, Patrice Ladwig. Cambridge: Cambridge University Press: 238-260.

VINOGRadova, Tatiana 2017: Dnevniki V.M. Alekseeva v 'Sinologicheskoi kartoteke' uchenogo [Academician V.M. Alekseev's diaries in "Sinological catalogue" of the scientist]. Obschestvo i gosudarstvo $v$ Kitae [State and Society in China]: 239-253.

ZavidovskaiA, Ekaterina \& Rud, Polina 2020: "Eluosi hanxuejia alike 1912 nian fuhua shouji de minjian zongjiao wenshu ji tuxiang 俄羅斯漢學家阿理克 1912 年赴華收 集的民間宗教文書及圖象” [Materials on popular religion collected by the Russian Sinologist Vasilii Alekseev during his expedition to the Southern China in 1912]. Minsu quyi 民俗 曲藝 [Journal of Chinese ritual, theatre, and folklore], 207 (2020.3): 255-99.

ZaVIDOvSKAIA, Ekaterina 2019: Eluosi hanxuejia alike zai hua nanbei shouji de lingfu 俄 羅斯漢學家阿理克在華南北收集的靈符 [Talismans collected in the northern and southern China by Russian sinologist Alekseev]. In: Nianhua shijie de xueshu goujian. Di sanjie zhongguo muban nianhua guoji yantaohui lunwenji 年画世界的学术构建。第 四届中国木板年画国际研讨会论文集 [Proceedings of the 3rd International conference on Chinese woodblock popular prints "Scholarly reconstruction of the popular print, PRC, Tianjin, October 16-17]: 96-110. 